\title{
Deregulation of Diesel and Petrol Pricing in Ghana: Perspectives of Commercial Drivers
}

\author{
Broni Bediako E ${ }^{1 *}$, Ocran $\mathrm{D}^{1}$, Amenya $\mathrm{PEK}^{1}$ and Marwa $\mathrm{SN}^{2}$ \\ ${ }^{1}$ Department of Petroleum and Natural Gas Engineering, University of Mines and Technology, \\ Ghana \\ ${ }^{2}$ Graduate, University of Mines and Technology, Ghana
}

*Corresponding author: Eric Broni-Bediako, Department of Petroleum and Natural Gas Engineering, University of Mines and Technology, Ghana, Tel: +233243052455; Email: ebronibediako@umat.edu.gh

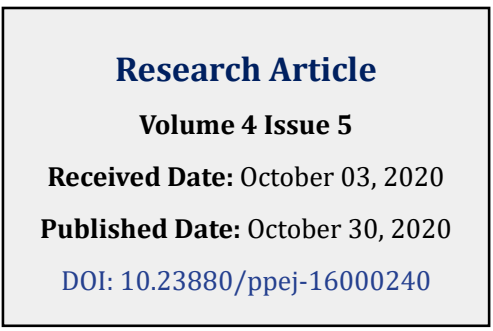

\section{Abstract}

The process to deregulate the pricing of petroleum products kept evolving until July 2015 where fuel prices were completely deregulated, and managed by Bulk Distribution Companies (BDCs) and Oil Marketing Companies (OMCs) under supervision of the National Petroleum Authority (NPA). This phase of the deregulation policy ended the subsidy regime. Deregulation policy was implemented to help stabilise price hikes. As a land mark policy, deregulation has implications. This research assessed perspectives of commercial drivers on deregulation of diesel and petrol pricing in Ghana using Tarkwa as a test case. The methods employed include field visits to lorry stations in Tarkwa; interviews and questionnaire administration; and statistical analysis of data. The study revealed that majority of commercial drivers are aware of the implementation of the deregulation policy in Ghana but do not understand its effects. All the commercial drivers revealed that there are different prices of diesel and petrol at pump stations. Majority were of the view that their choice of a pump station depends on both the price and quality of the fuel, and the proximity of the pump station to their operations. All commercial drivers asserted that the deregulation policy has negatively affected their business. It is therefore recommended that the NPA should insist on price reduction nationwide when prices of fuels are reviewed downwards and also ensure that the right information is efficiently communicated to consumers of petrol and diesel in Ghana especially commercial drivers to minimise the risks of anxiety.

Keywords: Commercial drivers; Deregulation; Diesel; Petrol; Subsidy

Abbreviations: NPA: National Petroleum Authority; OMCs: Oil Marketing Companies; IMF: International Monetary Fund; GGL: Goldfields Ghana Limited; GMC: Ghana Manganese Company; VAT: Value Added Tax; BDCs: Bulk Oil Distribution Companies; APPPF: Automatic Petroleum Product Pricing Formula.

\section{Introduction}

The issue of the pricing of petroleum products has dominated public discourse and policy contestations for years. The difference in opinions has focused on subsidy removal, deregulation or appropriate pricing. At the heart of each of these is the pricing and therefore, the cost of petroleum products to consumers. Pricing of petroleum products such as petrol and diesel in Ghana has experienced abnormal hikes. This throws the economy of Ghana off balance. Petroleum products initially priced by the National Petroleum Authority (NPA), is now executed by Oil Marketing Companies (OMCs). In 2001, the first attempt was made to liberalise fuel prices with the introduction of automatic price setting mechanism. This was aimed at linking local fuel prices with international ones. It was however, abandoned at the end of the year and prices were once again controlled by government. It was reintroduced in 2003 and was once again abandoned. An impact analysis by the International Monetary Fund (IMF) 


\section{Petroleum \& Petrochemical Engineering Journal}

concluded that the fuel subsidy drained a great portion of public resources. As a result, price formula was brought back in 2005 and NPA was set-up by the passage of the NPA Act, 2005 [Act 691] to oversee the deregulation of the sector. The removal of fuel subsidy largely occurred in 2013 [1].

The introduction of the deregulation policy by government was to reduce the huge debts government owed OMCs which deprived OMCs the capital needed for effective and sustainable business operations [2]. OMCs directly communicate with consumers by setting their own prices with the NPA ensuring that these products sold were up to standard. It was also necessary to put an end to government subsidies, reduce foreign exchange losses, reduce prices of petroleum products since the government cannot play politics with pricing and to invite more private players into the sector. However, the industry players foresee that prices are likely to increase with the deregulation policy due to the rate of the cedi's depreciation [3]. Is the deregulation policy serving its purpose? This research seeks to examine the perspectives of commercial drivers on the deregulation of diesel and petrol price. This will also help to ascertain the impact of the deregulation policy on commercial drivers since its inception.

\section{Study Area}

Tarkwa, the capital of the Tarkwa-Nsuaem Municipality in the Western Region of the Republic of Ghana is a town in the south-western part of Ghana (Figure 1).

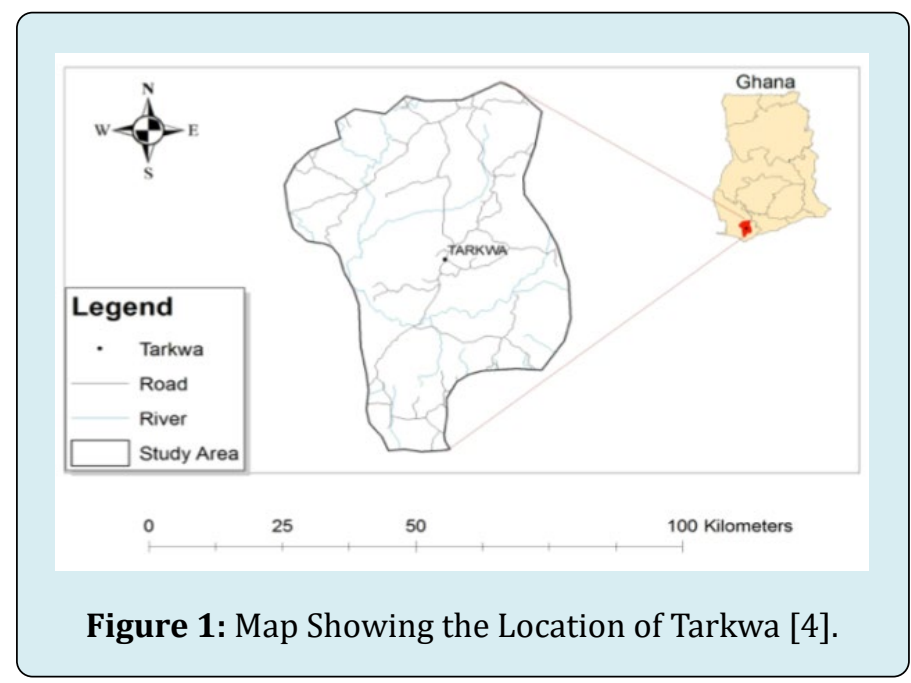

It is located about $85 \mathrm{~km}$ from Takoradi the Regional capital and about $306 \mathrm{~km}$ from Accra. The town is endowed with gold and manganese mining companies like Goldfields Ghana Limited (GGL), Anglo-gold Ashanti (AGA) and Ghana Manganese Company (GMC). Most of the habitants are migrants from other parts of the country $[4,5]$.

\section{Fuel Pricing System in Ghana}

The three main factors behind products pricing in Ghana are government policies (taxes and levies), exchange rate (Forex) and global crude oil price. Exchange rate and crude oil price directly feed into ex-refinery price of the petroleum products. Taxes, levies and margins are added to the exrefinery prices to produce the ex-pump prices [6]. The price of crude oil on the international market is an important determinant of fuel prices in Ghana. As prices of crude oil globally increases, prices of fuel are expected to also increase even if the local currency (Cedi) is stable. In addition to the above mentioned, exchange rate also influences the prices of fuel in Ghana. The exchange rate system in Ghana is not stable since the value of the Cedi keeps reducing when compared to the universal US dollars. As a result of this, consumers are made to pay more when buying fuel at pump sites (petrol stations). The taxes and levies per litre include, Excise Duty, Energy Debt Recovery Levy, Road Fund Levy and Energy Fund Levy amongst others. Each tax component and margins also attract about $17.5 \%$ Value Added Tax (VAT) which consumers pay. These fuel taxes and levies raise fuel prices [7]. Table 1 gives an outline of various taxes imposed on fuel prices.

\begin{tabular}{|c|c|}
\hline $\begin{array}{c}\text { Energy Debt } \\
\text { Recovery Levy }\end{array}$ & $\begin{array}{c}\text { To help debt recovery of Tema Oil } \\
\text { Refinery, downstream petroleum sector, } \\
\text { power generation and infrastructure. }\end{array}$ \\
\hline Road Fund & For road maintenance. \\
\hline Energy Fund & To support energy commission activities. \\
\hline $\begin{array}{c}\text { Price } \\
\text { Stabilization } \\
\text { and Recovery } \\
\text { Levy }\end{array}$ & $\begin{array}{c}\text { To help absorb shocks resulting from } \\
\text { price hikes for consumers, so it helps } \\
\text { stabilise petroleum prices. }\end{array}$ \\
\hline $\begin{array}{c}\text { Marketers } \\
\text { Margin }\end{array}$ & $\begin{array}{c}\text { Gross revenue an OMC will gain from } \\
\text { every litre sold. }\end{array}$ \\
\hline $\begin{array}{c}\text { Fuel Marking } \\
\text { Margin }\end{array}$ & $\begin{array}{c}\text { Payment made when fuels are marked to } \\
\text { avoid smuggling, altering of products or } \\
\text { tax revenue loss. }\end{array}$ \\
\hline $\begin{array}{c}\text { BOST Margin } \\
\text { Payments made to cover maintenance } \\
\text { and operating cost of petroleum products }\end{array}$ \\
\hline $\begin{array}{c}\text { Primary } \\
\text { Distribution } \\
\text { Margin }\end{array}$ & $\begin{array}{c}\text { To make up for costs incurred in moving } \\
\text { petroleum products from costal depots to } \\
\text { in land depots. }\end{array}$ \\
\hline $\begin{array}{c}\text { Dealers } \\
\text { Margin }\end{array}$ & $\begin{array}{c}\text { Gross revenues petroleum retailers earn } \\
\text { operating an OMC. }\end{array}$ \\
\hline $\begin{array}{c}\text { Special } \\
\text { Petroleum Tax }\end{array}$ & $\begin{array}{c}\text { Makes about 15\% of Ex-depot price and } \\
\text { forms part of VAT reforms. }\end{array}$ \\
\hline
\end{tabular}

Table 1: Breakdown of Taxes/Levies imposed on Ex-Pump Prices [8]. 


\section{Petroleum \& Petrochemical Engineering Journal}

\section{Deregulation Policy of Petroleum Product Pricing in Ghana}

The deregulation policy in Ghana came by the passage of the NPA Act in 2005. The promulgation of Act 691 of the NPA [9] began the deregulation regime in Ghana. According to the Act, the NPA is mandated to regulate, oversee and monitor activities in the petroleum downstream industry and where applicable do so in pursuance of the prescribed petroleum pricing formula. To achieve the said object, NPA among other things shall promote fair competition amongst petroleum service providers, collect and compile data on international and domestic petroleum production, supply and demand, inventory of petroleum products, and pricing of petroleum products [9]. Before 2005, the government and individuals who imported petroleum products in collaboration with other agencies decided the prices at which they will sell their products. When the NPA Act was enacted in 2005, the government negotiated with the importers of petroleum products to determine the price at which they would sell their products. The regulator attempts to verify the import costs of the BDCs and by extension fixes the prices of enduser petroleum products taking into account subsequent taxes and levies. The NPA was in charge of pricing fuel until 2015 when the phase evolved to OMCs importing and pricing fuels on their own. The NPA still monitors overall operations to ensure peace by setting price ceilings for OMCs to work within. Demand and supply now adversely influence the prices of petrol at petrol stations [3].

Part of the deregulation process includes the NPA monitors the prices set by OMCs which they are compelled to display at their retail outlets. The NPA relates that, this is to ensure that all petroleum service providers apply the prescribed petroleum pricing formula in the right way. According to the formula, the OMCs submit their indicative ex-pump prices to the NPA two days before every pricing window. The submitted prices represent the maximum the oil marketer can charge. OMCs can reduce their ex-pump prices below submitted prices but cannot increase prices above. The NPA ensures that the ex-pump price quoted by a particular Oil Marketer remains equal throughout its retail outlets. This Phase of the deregulation policy has completely ended the subsidy regime [10]. The policy has a primary objective to put an end to government subsidies on crude oil and petroleum products geared towards sanitizing the country's petroleum sector. The deregulation policy was put in place to reduce foreign exchange losses, reduce prices of petroleum products since the government cannot play politics with pricing and to invite more private players into the sector as well as introduce the ultimate benefit and protection of the consumer [3]. The deregulation of petroleum-product prices, and hence the removal of fuel subsidy in Ghana implied that, people will pay the actual price and this will eliminate distortions in the market, and increase efficiency in resource allocation for healthy growth of the nation. Also, it will limit smuggling of petroleum products into Ghana $[2,11]$.

\section{Key Players in Petroleum Products Pricing in Ghana}

The key players in petroleum products pricing are grouped in state actors and non-state actors. These actors are organisation and individual whose action influences petroleum products pricing. The state actors in Ghana are the Ministry of Energy and Petroleum, and National Petroleum Authority. They are mandated by the government to oversee the management of the petroleum industry. The non-state actors include BDCs and OMCs. They give ideas, suggest methods of actions, shape political agenda and also intervene in political issues.

\section{Ministry of Energy and Petroleum}

The Ministry of Energy and Petroleum plays a supervisory role when implementing the prices of fuel. The mission of the ministry is to develop and ensure reliable supply of high-quality energy services at minimum cost to all sectors of the economy through the formulation, implementation, monitoring and evaluation of policies. It aims at making energy services generally accessible and available in an environmentally sustainable way $[12,13]$.

\section{National Petroleum Authority (NPA)}

NPA was established in 2005 by the Act of Parliament [NPA Act, 2005 (Act 691)] of the Republic of Ghana. It was established to replace the Ghana National Petroleum Tender Board which was regulating the prices of petroleum products. The NPA Act also established a fund known as the Unified Petroleum Pricing Fund (UPPF). Their objectives were to guarantee a regular supply of petroleum nationwide, ensure that prices of petroleum product include a model that estimated cost of distribution and achieve an efficient petroleum products distribution system [9].

\section{Bulk Oil Distribution Companies (BDCs)}

The BDCs are licensed by the NPA as bulk oil distributors. They import crude oil, procure, store, distribute and sell petroleum products specifically to bulk customers. They serve as petroleum product suppliers in times of fuel shortages. They also distribute their products to accredited OMCs who retail nationwide $[14,15]$.

\section{Oil Marketing Companies}

The OMCs in Ghana buy and sell refined petroleum products to bulk consumers such as offshore companies, 


\section{Petroleum \& Petrochemical Engineering Journal}

national securities, Volta Aluminium Company (VALCO), Volta River Authority (VRA) and the public such as the fuel stations and other fuel selling outlets. These companies also supply petroleum products in times of crises with the approval of the NPA [14-18].

\section{Resources and Methods}

The survey strategy was employed to conduct this research because it is an effective technique to get opinions, attitudes and descriptions from respondents. Both primary and secondary data were used in conducting the study. Both closed and open-ended questions were used to design the questionnaires. Primary data was obtained from the two main lorry stations in Tarkwa. A total of 183 questionnaires were administered. In all, 102 of the respondents were taxi drivers and 81 bus drivers. Responses to the questionnaires were obtained through interviews and interactions with the commercial drivers. The secondary data was obtained from National Petroleum Authority.

\section{Results and Discussion}

This section presents perspectives of commercial drivers on deregulation policy of diesel and petrol pricing in Ghana using Tarkwa as a test case. Under this section the following would be discussed: demographic data of respondents; knowledge about deregulation policy on petroleum products; deregulation and consumers' perspectives on fuel purchase; and impact of petrol and diesel deregulation on commercial drivers.

\section{Demographic Data of Respondents}

Age Range: Table 1 shows the gender and age range of the respondents. All commercial drivers assessed were males. The results depict a typical transportation sector in Ghana where driving is seen as a male profession than being a profession for both men and women. 25 of the drivers were between the ages of $18-30$. This is $13.66 \%$ of the total 183 questionnaires administered. $61.75 \%$ of the respondents were between the ages of $31-40$ and $22.40 \%$ of the drivers were between the ages of $41-50$. Only $2.19 \%$ of the respondents were above 50 years (Table 1).

Marital Status: Table 2 shows the marital status of the respondents. From Table 2, 86.34\% of the respondents were married. This shows that majority of the commercial drivers have marital responsibilities in addition to their job and would therefore expect that the deregulation policy on diesel and petrol pricing will impact their lives positively. $7.10 \%$ and $5.46 \%$ of the respondents were single and divorced respectively. $1.09 \%$ of the drivers interviewed were widowers.
Educational Level: Table 3 shows the educational level of respondents. Most (65.0\%) of the drivers had gone through JSS/SSS education followed by $29.51 \%$ of the drivers with 0/A-level certificate. $3.83 \%$ of the drivers were degree holders and $1.6 \%$ had no formal education. On the whole, majority of the people sampled had gone through some form of formal education and would therefore be able to appreciate the deregulation policy on diesel and petrol pricing (Table 3).

\begin{tabular}{|c|c|c|}
\hline Item & \multicolumn{2}{|c|}{ Commercial Drivers } \\
\hline Gender & Number & Percentage (\%) \\
\hline Male & 183 & 100 \\
\hline Female & 0 & 0 \\
\hline Total & $\mathbf{1 8 3}$ & $\mathbf{1 0 0}$ \\
\hline \multicolumn{3}{|c|}{ Age Range } \\
\hline 18-30 years & 25 & 13.66 \\
\hline 31-40 years & 113 & 61.75 \\
\hline 41-50 years & 41 & 22.4 \\
\hline 51 and above years & 4 & 2.19 \\
\hline Total & $\mathbf{1 8 3}$ & $\mathbf{1 0 0}$ \\
\hline
\end{tabular}

Table 1: Gender and Age Range of Respondents.

\begin{tabular}{|c|c|c|}
\hline \multirow{2}{*}{ Item } & \multicolumn{2}{|c|}{ Commercial Drivers } \\
\cline { 2 - 3 } & No. & Percentage (\%) \\
\hline Single & 13 & 7.1 \\
\hline Married & 158 & 86.34 \\
\hline Divorced & 10 & 5.46 \\
\hline Widowed & 2 & 1.09 \\
\hline Total & $\mathbf{1 8 3}$ & $\mathbf{1 0 0}$ \\
\hline
\end{tabular}

Table 2: Marital Status of Respondents.

\begin{tabular}{|c|c|c|}
\hline \multirow{2}{*}{ Item } & \multicolumn{2}{|c|}{ Educational Level } \\
\cline { 2 - 3 } & No. & Percentage (\%) \\
\hline JSS/SSS & 129 & 65.06 \\
\hline O/A-Level & 44 & 29.51 \\
\hline Diploma/Certificate & 0 & 0 \\
\hline Degree & 7 & 3.83 \\
\hline None & 3 & 1.6 \\
\hline Total & $\mathbf{1 8 3}$ & $\mathbf{1 0 0}$ \\
\hline
\end{tabular}

Table 3: Educational Level of Respondents.

\section{Knowledge about Petroleum Deregulation Policy}

Figure 2 shows the responses of the commercial drivers on their knowledge about the deregulation policy on diesel 


\section{Petroleum \& Petrochemical Engineering Journal}

and petrol. $33.0 \%$ of the commercial drivers were aware of the deregulation policy whilst $67.0 \%$ were not aware of the policy (Figure 2). All the respondents (100\%) indicated that, they do not understand the deregulation policy though $33.0 \%$ were aware of the policy. Out of the 183 of commercial drivers interviewed, 20.21\% knew the Automatic Petroleum Product Pricing Formula (APPPF) and 79.78\% had no idea about APPPF. Out of the 37 commercial drivers who had knowledge about APPPF only $6.01 \%$ of them understand the APPPF (Figure 1). A question was asked on whether the formula for the pricing petroleum has always been covered by secrecy. Majority (94.54\%) of the drivers were of the view that pricing formula has not been covered by secrecy and the rest $(5.46 \%)$ agreed that it has been covered by secrecy. All (100\%) drivers interviewed had knowledge about the different prices of diesel and petrol displayed at different pump stations. This knowledge will help drivers to select best place to purchase fuels in terms of price (Figure 2).

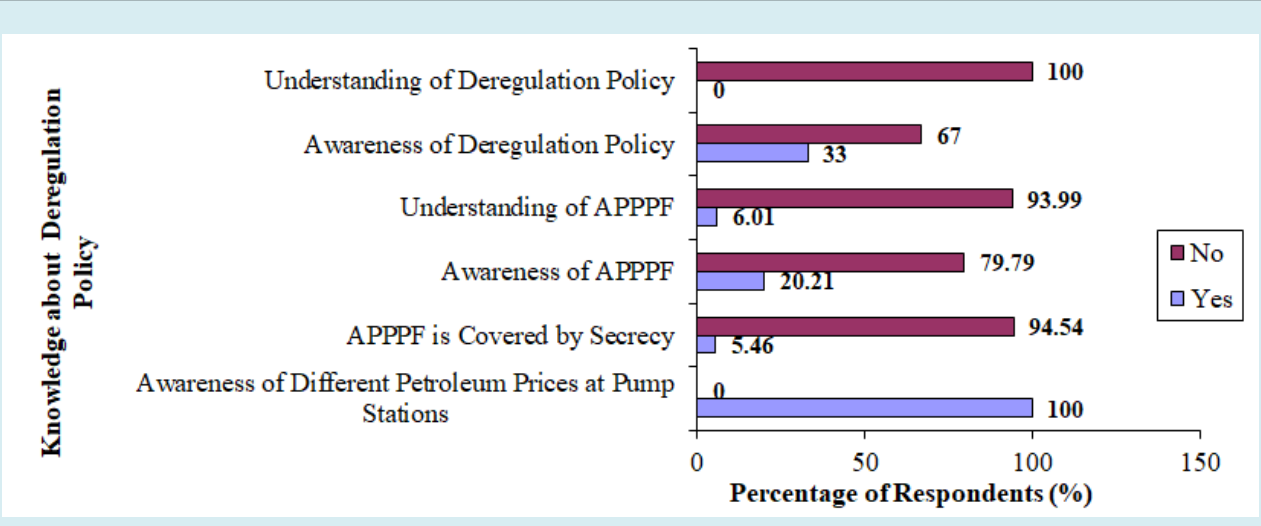

Figure 2: Knowledge about Petroleum Deregulation Policy.

\section{Perspectives of Drivers on Fuel Purchase}

Figure 3 shows the perspectives of commercial drivers on fuel purchase. Out of 183 respondents, $93.4 \%$ of the commercial drivers agreed that price of fuel is the major factor for buying petroleum products at a particular pump station whilst $6.6 \%$ disagreed. Majority of the commercial drivers $(89.07 \%)$ revealed that they compare prices of fuel to determine cheapest pump station before buying. The $10.93 \%$ of the respondents who do not consider prices explained that there is no time to monitor prices of the various pump stations to ascertain the cheapest as profits depend on the number rounds. To them, it is time wasting in comparing prices of the various pump stations.

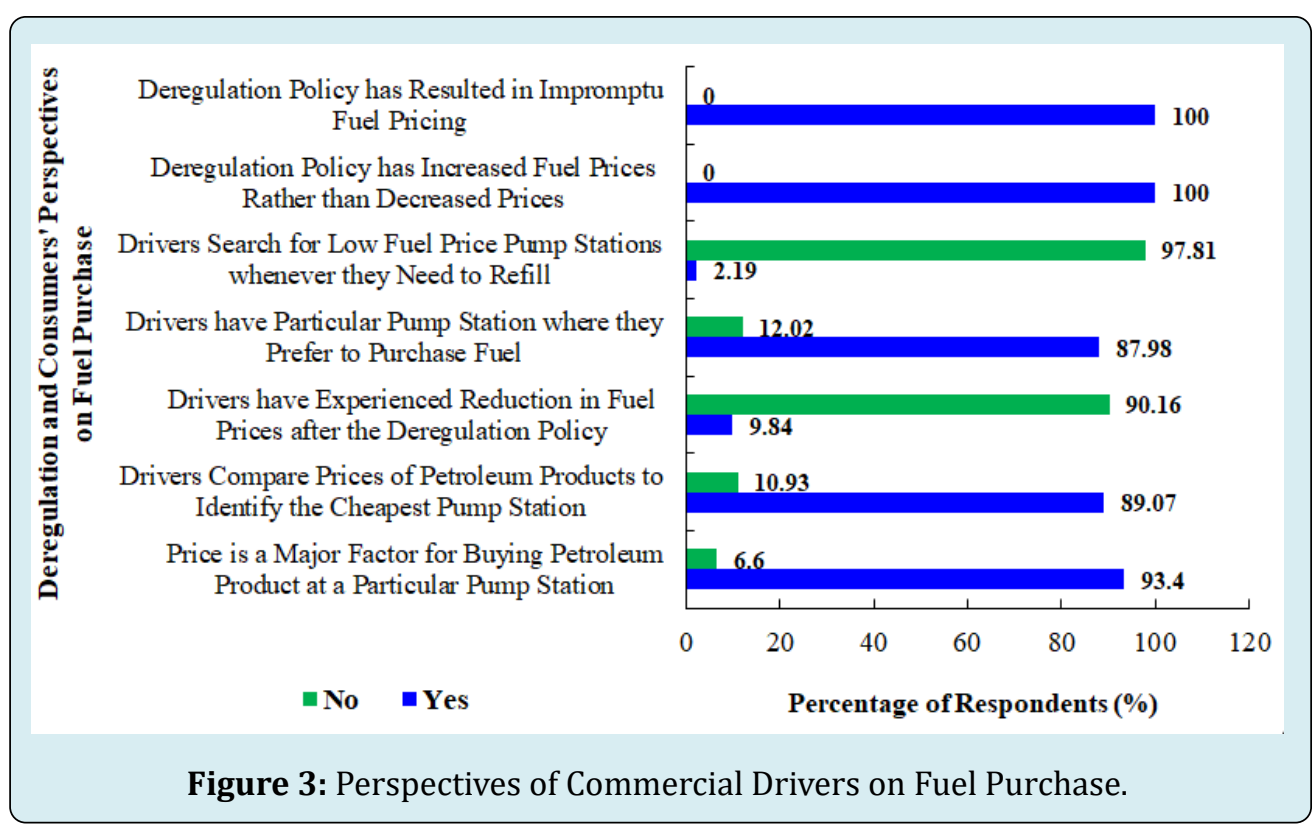




\section{Petroleum \& Petrochemical Engineering Journal}

$90.16 \%$ of the respondents asserted that they have never experienced any reduction in fuel prices since the deregulation policy started. The $9.84 \%$ of the respondents who had experienced price reduction also indicated that the reductions could not be compared to the price increment. This could be the reason why majority responded that they had never experienced reduction though there has been a reduction of price. The respondents also indicated that retail centres (pump stations) takes very long time to adjust prices when there is price reduction contrary to when there is increase in fuel price. $87.98 \%$ of the commercial drivers revealed that they have a preferred pump stations where they always buy their fuel whilst $12.02 \%$ of the drivers do not have a preferred pump station. The most preferred pumps stations by the commercial drivers are stated-owned companies followed by international oil companies and private-owned companies.

179 (97.81\%) out of 183 commercial drivers indicated that they do not search for low fuel price pump stations whenever they need to refill. However, 4 (2.19\%) drivers revealed that they always search for low fuel pump stations. To the respondents, they prefer to consider the proximity of pump station to search for low fuel price. All the commercial drivers $(100 \%)$ agreed that deregulation has increased fuel prices rather than reduced prices and also led to impromptu pricing (Figure 3). Figure 4 shows what motivates commercial drivers to select a particular pump station. Out of the 161 commercial drivers who have preferred pump stations, $70.0 \%$ of them are motivated by the price and quality of the fuel whilst $30.0 \%$ of the commercial drivers indicated that they are motivated by the price only since there is no significant difference in fuel quality (Figure 4).

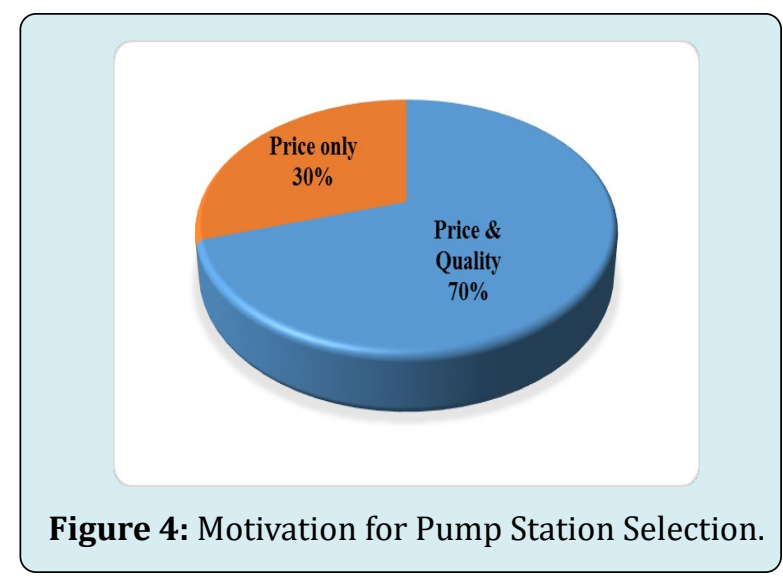

\section{Impact of Deregulation of Petrol and Diesel on Commercial Drivers}

Figure 5 shows the impact of deregulation of petrol and diesel on commercial driver. From Figure 5, all the drivers $(100 \%)$ agreed that the deregulation policy has affected them negatively in terms of their daily income. According to the commercial drivers, fuel prices increases more often than transport fares. A fuel reduction does not often happen due to weak cedi. Majority (98.91\%) of the commercial drivers revealed that fuel increase is always impromptu resulting in anxiety and confusion as vehicle owners or drivers would have to absorb losses brought by increments of fuel prices in between increment of transport fare (Figure 5). 82.51\% of the respondents revealed that the impromptu increase in diesel and petrol leads to misunderstanding between them and their employers due the amount of money that must be paid to their employers. The rest of the respondents (16.94\%) with alternative view were owners of the commercial vehicle.

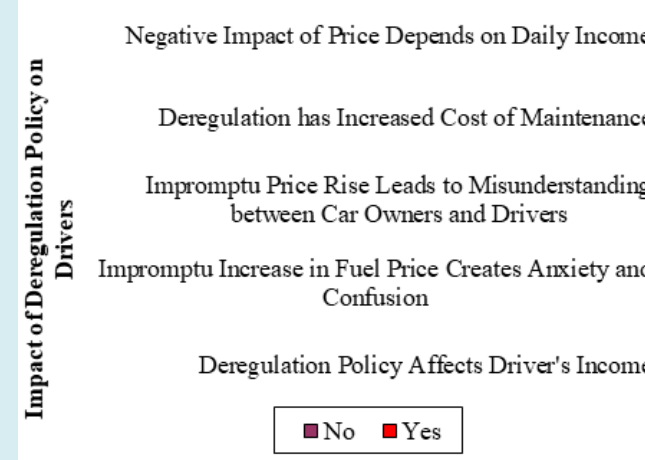

Figure 5: Impact of Deregulation of Petrol and Diesel on Commercial Drivers.
All $(100 \%)$ the respondents asserted that, the deregulation policy has indirectly affected the cost of maintenance. Prices of spare parts, fan belts, tyres and the like have increased since the deregulation policy started (Figure 5). $72 \%$ of the commercial drivers revealed that the negative effect of price rise is greatly felt when passengers decide to 


\section{Petroleum \& Petrochemical Engineering Journal}

walk when the distance is short. This scenario affects daily incomes. However, $28 \%$ of the commercial drivers disagreed with the assertion.

The results from Figure 5 affirm the point that a large portion of the driver's daily income is always spent to purchase fuel to run the business. Majority of the commercial drivers $(67.75 \%)$ who are married have difficulty to manage both home and work expenses due to low income. To the commercial drivers, the difficulty in managing their homes is due to the deregulation policy which to them does not favour their operations because prices are hardly reviewed downwards and this does not always translate to a reviewed in transportation cost.

\section{Conclusions and Recommendations}

From the analysis, the following conclusions could be drawn:

1. All commercial drivers interviewed were males. This depicts a typical transportation sector in Ghana where driving is seen as a male profession than being a profession for both men and women.

2. Majority of the respondents indicated their awareness of deregulation policy on diesel and petrol pricing but asserted that they do not understand the policy.

3. All $(100 \%)$ the respondents indicated that they are aware of the different petroleum prices at pump stations.

4. The respondents revealed that though price is the major determinant of their choice of pump stations, they do not have the time of comparing prices when they are ready to buy fuel.

5. The respondents indicated that the deregulation policy has negatively affected their business because prices of diesel and petrol are mostly reviewed upwards and does not always correspond to increase in transportation cost.

It is therefore recommended that:

1. National Petroleum Authority should insist on price reduction nationwide when prices of fuels are reviewed downwards.

2. National Petroleum Authority should ensure that the right information is efficiently communicated to consumers of Petrol and Diesel in Ghana especially commercial drivers to minimize the risks of anxiety.

\section{References}

1. Cooke EFA, Hague S, Cockburn J, Lahga AE, Tiberti L (2014) Estimating the Impact on Poverty of Ghana's Fuel Subsidy Reform and Mitigating Response. Partnership for Economic Policy Working Paper pp: 1-35.

2. Addae E, Ackah I (2017) Inflation Dynamics in Pre- and Post-Deregulation Era in Ghana: Do Petroleum Prices Have any Influence?. Munich Personal RePEc Archive pp: $1-12$.

3. Acheampong T, Ackah I (2015) Petroleum Product Pricing, Deregulation and Subsidies in Ghana: Perspectives on Energy Security. Munich Personal RePEc Archive pp: 1-13.

4. Nyarko C (2016) Modelling Prevalence and Incidence Rates of Chlamydia Trachomatis Infection in Western Region of Ghana. PhD Thesis, University of Mines and Technology, Tarkwa, Ghana. pp: 1-156.

5. Akabzaa T, Darimani A (2001) Impact of Mining Sector Investment in Ghana: A Study of the Tarkwa Mining Region. Report Prepared for SAPRI pp: 1-71.

6. Adam MA (2009) Petroleum Products Pricing in GhanaEconomics or Politics. Centre for Energy Economics and Policy (CEEP), Ghana.

7. Nuhu P (2015) Deregulation of the Petroleum SectorPart 2. Energy Management, Oil and Gas, Mikashini's Blog, pp: 1-3.

8. Dei-Tutu DN (2017) Breakdown of Taxes, Levies and Margins Imposed on Ex-Pump Prices.

9. Anon (2005) National Petroleum Authority Act 691. NPA, pp: 1-29.

10. Obiukwu O (2015) Despite Deregulation, Ghana's Oil Marketers are Reducing Fuel Prices.

11. Kwakye JK (2011) The Petroleum Sector should be Fully Deregulated and Depoliticized in the National interest. Institute of Economic Affairs 19(6): 1-6.

12. Akosa F (2016) The Political Economy of Petroleum Pricing in Ghana. Unpublished MPhil Thesis, University of Ghana pp: 1-136.

13. Anon (2018) Ministry of Energy and Petroleum.

14. Broni-Bediako E, Dankwa KO (2013) Assessment of Liquefied Petroleum Gas (LPG) Utilisation in Ghana, A study at Tarkwa. International Journal of Science and Technology Research 2(9): 6-10.

15. Amponsah R, Opei F K (2014) Ghana's Downstream Petroleum Sector: An Assessment of Key Supply Chain Challenges and Prospects for Growth. Journal of Management and Business Studies 7(3): 441-448. 


\section{Petroleum \& Petrochemical Engineering Journal}

16. Asamoah GN (2011) The Impact of the Financial Sector Reforms on Savings, Investments and Growth of Gross Domestic Product (GDP) in Ghana. International Business and Economics Research Journal 7(10): 2029.
17. Asare BE (2011) International Politics: The Beginnersr's Guide. Yamens Press Ltd., Accra-Ghana.

18. Suleiman M (2017) Taxes Choke Fuel Prices - Chamber of Petroleum Consumers. 